\title{
A NEW MODEL OF TECHNOLOGY-DRIVEN E-FLIPPED CLASSROOM FOR STRATEGIC MANAGEMENT STUDENTS' ENGAGEMENT DURING AND POST COVID-19 PANDEMIC
}

\author{
Yusmani Mohd Yusoff ${ }^{1} \bowtie$, Hafinas Halid ${ }^{2}$, Nurhazlini Rahmat ${ }^{3}$ \\ ${ }^{1}$ Institute for Business Competitiveness, Standards, \& Sustainability Initiative, Universiti Utara Malaysia, \\ Malaysia. \\ ${ }^{2}$ School of Business \& Social Sciences, Albukhary International University, Malaysia. \\ ${ }^{3}$ Centre for Languages, Sultan Abdul Halim Mu'adzam Shah International Islamic University, Malaysia.
}

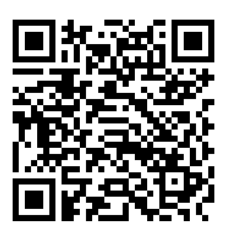

\section{ABSTRACT}

The occurrence of unexplained viral pneumonia has been reported in Wuhan, China in the end of 2019. Since then, Higher education institutions (HEIs) in Malaysia have decided to shift learning practices towards online learning systems to ensure the teaching and learning activities continue as usual. Universiti Utara Malaysia (UUM) established online classes, through live broadcast using Webex and to build a three-foot "cloud" podium for other network teaching styles. Therefore, this paper proposed a new model of a technology-driven e-flipped classroom for students' engagement during and post COVID-19 pandemic. Data was collected from 230 students of Strategic Management class, Universiti Utara Malaysia in the semester $12020 / 2021$. Based on the analysis, this study found that Edmodo as an online learning platform and flipped classroom approach enhances students' engagement through online activities carried out on their self-paced learning styles.

Received 5 November 2021
Accepted 16 December 2021

Published 31 December 2021

CorrespondingAuthor

Yusmani Mohd Yusoff,

yusmani@uum.edu.my

DOI

10.29121/granthaalayah.v9.i12.2021 .3356

Funding: This research received no specific grant from any funding agency in the public, commercial, or not-for-profit sectors.

Copyright: (C) 2021 The Author(s). This is an open access article distributed under the terms of the Creative Commons Attribution License, which permits unrestricted use, distribution, and reproduction in any medium, provided the original author and source are credited.

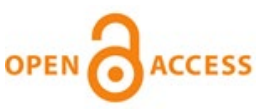

Keywords: Model of Technology, Technology Driven, Flipped Classroom, Student Engagement

\section{INTRODUCTION}

Since the end of 2019, the occurrence of unexplained viral pneumonia has been reported in Wuhan. On 12 January 2020, the World Health Organization (WHO) formally named the new coronavirus that caused the outbreak of pneumonia in Wuhan as "2019 New Coronary Virus (2019-nCoV)." In the same month, WTO declared that the outbreak of the new coronavirus had been classified as a public health emergency of international concern (PHEIC) and it named the pneumonia of the new coronavirus (COVID-19). The existence of COVID-19 has influenced our normal routines and also affected the education system as governments have established rules and regulations to tackle the outbreak, as governments in 49 countries have announced and implemented the closure of educational institutions to control the spread of COVID-19 UNESCO (2020). Higher education institutions have to shift from classroom teaching to online teaching platform in order to ensure that the teaching and learning activities continue as usual. In order to mitigate the transmission of the virus Higher education institutions (HEIs) in Malaysia have decided to shift learning practices towards online learning systems. Hence, Universiti Utara Malaysia (UUM) establishes online classes through live broadcast using Webex and builds a three-foot "cloud" podium for other network teaching styles, as well as for 
students, in compliance with the material and specifications of the program.

\section{Issues between Online Learning and Students Engagement}

Many parties have agreed on the continuity of the teaching and learning process during the Covid-19 pandemic through an online learning platform. Although lecturers and students have been used to the physical class design; however, when all the classes are shifted to online teaching, there are still many challenges to be looked into, such as the teaching and learning platforms, technical skills, and teaching materials. Besides, this shift has also raised issues of familiarising stakeholders with technology, face-to-face contact loss, and active student engagement during the implementation of online learning. Online learning involves comprehensive involvement from lecturers and most importantly from students. Although technology plays a role in facilitating online learning, access to highquality digital contents such as access to the internet and learning software is very important, especially during lockdown (The Star, March 29, 2020). On the other hand, student engagement is a continuous challenge to any lecturer, whether the teaching is done offline or online. Student engagement in online learning is very important because online learning platforms limits students' opportunity to interact with their students Martin and Bolliger (2018). In UUM, there is a particular subject that prioritises the element of student engagement in teaching and learning, namely Strategic Management (offered by the School of Business Management, College of Business). The Strategic Management course exposes students to the management of an organisation's resources to achieve its goals and objectives. It consists of an ongoing process of formulation, implementation of actions, and evaluation and control of strategies to ensure that an organisation moves in line with its external environment. The Strategic Management Course has three (3) learning outcomes (CLOs) namely:

1) Explain the basic concepts in strategic management and various types of strategies. (C2)

2) Apply strategic approaches, techniques, and tools in strategic management. (C3)

3) Identify potential alternative strategies from issues or problems of business and management in a given situation. (C4, A4)

All of these outcomes can be achieved through students' engagement as well as comprehensive audit strategic activities that require them to communicate among themselves. Therefore, transferable skills are essential in this course; where they can be achieved through teamwork, communication, and problem-solving skills. All these skills are combined in one concept: active student engagement. Student engagement in online learning activities is seen as very critical aspect due to the COVID-19 pandemic issue where all walks of life are restricted to movement control order implemented by the government. Therefore, to minimise disruption to teaching and learning activities, the university must ensure an effective online platform approach for all its students as well as establishing an effective online learning platform that can stimulate students' engagement in online learning activities.

However, the extent to which the university makes plans and preparations to activate online learning as a whole when we were hit by the COVID-19 pandemic in 2020 took place suddenly and has spread quickly in 2020. The use of technology as a medium of online learning requires overall student engagement which according 
to Bulger et al. (2008) student engagement is a concept of effort, interest, motivation, and time spent by students in the task learning. Does the implementation of 100 per cent distance learning by prioritising online learning motivate all students to be actively engaged? Undeniably, the selection of an effective platform will affect student engagement, especially in Strategic Management courses where the CLOs are closely related to overall student engagement with classmates for task completion and so on.

Online learning is not straightforward, as the learning goals should always be completely enforced through online media, as the use of social media such as Edmodo in higher education has increased learning, increased participation and engagement, as well as increased content dissemination, pedagogy, and information sharing Parusheva et al. (2018). In addition to the above, flipped classrooms are known to be an active form of teaching and learning, enabling teachers to use higher-level thought to educate, and motivating students to engage positively in a range of learning experiences Chen et al. (2017). Extracurricular activities such as video courses and flipped online discussion topics or issues ahead allow students to gain knowledge and skills, which will enhance their fulfilment with flipped classroom learning Murillo-Zamorano et al. (2019).

\section{Design Principle for Online Learning to Enhance Students Engagement}

Taken together with the usage of Edmodo and flipped classroom, the purpose of this paper is to identify whether Edmodo can be a significant platform for online learning where such learning can be integrated in the flipped classroom in the event of a crisis such as COVID-19, where face-to-face interaction is not allowed. Furthermore, this new method (Edmodo \& flipping the class classroom) can be used to support flexible blended learning post COVID-19 pandemic as to increase students' engagement in the Strategic Management subject.

This paper proposes a new model of a technology-driven e-flipped classroom for students' engagement during and post COVID-19 pandemic. The model of a technology-driven e-flipped classroom is designed using the concept of the conventional flipped classroom together with the integration of Edmodo as the implementation platform (Figure 1).

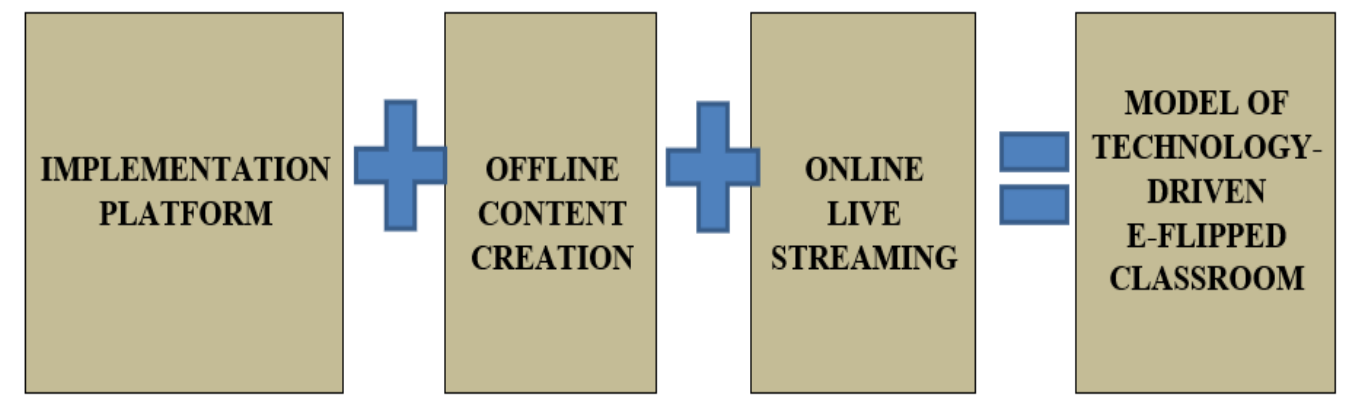

Figure 1 Proposed Model of Technology-driven e-flipped Classroom of Strategic Management

\section{Preparing for Flipped Classroom}

During the pandemic, the universities can replace the flipped classroom definition with offline content creation combined with online live streaming and implementation platform software. The proposed method is shown in Figure 1. Before the first lecture, students obtained the course outline consists of the information such as objectives of the course, course progress (14 weeks in total), 
textbook versions, and the proposition and method of the grade assessment through the UUM Online Learning portal. Lecturer also provided the information of the software for the implementation platform for the online learning and facilitate the students to download and install and test beforehand. Therefore, for this Strategic Management subject, the lecturer has utilised the online platform called Edmodo (Figure 2).

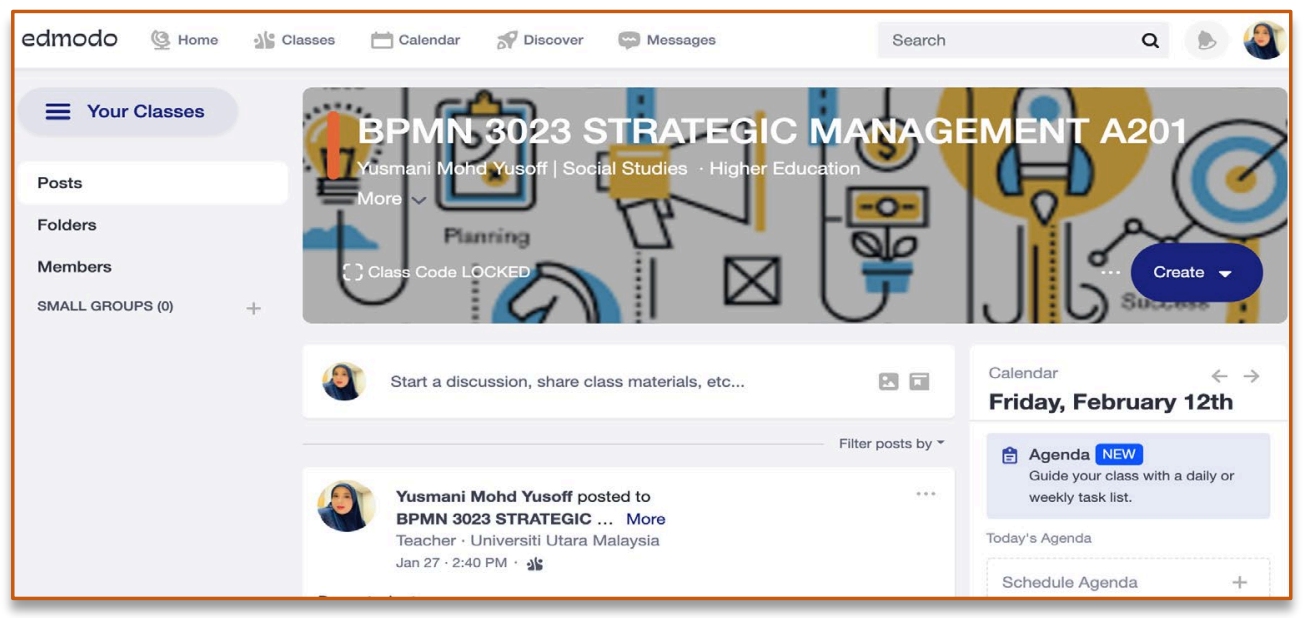

Figure 2 Edmodo Online Learning Platform for Strategic Management Subject

In the next step, the lecturer arranged for offline content creation by using easy tools like Microsoft PowerPoint, Canva, etc. The lecture videos were of vibrant colors and images, coupled with the videos from other sources (combined lecture videos or shared links) where the videos were recorded using Screencast-o-Matic software. This technique will direct the lecturers in creating content videos and will attract the students for their learning and engagement. Furthermore, after contents creation, the lecturer uploaded the videos in the online learning platform, Edmodo (Figure 3). Students have watched the videos, together with the slides on that particular topic before the live-streaming discussion. Live streaming discussion time is administered, instead of face-to-face learning setting in a traditional flipped classroom. Also, the educators should utilise an online live streaming tool that is appropriate for the teaching and learning activities as provided by their respective university, for instance, in UUM, Webex is used as an online live streaming tool (Figure 4). 

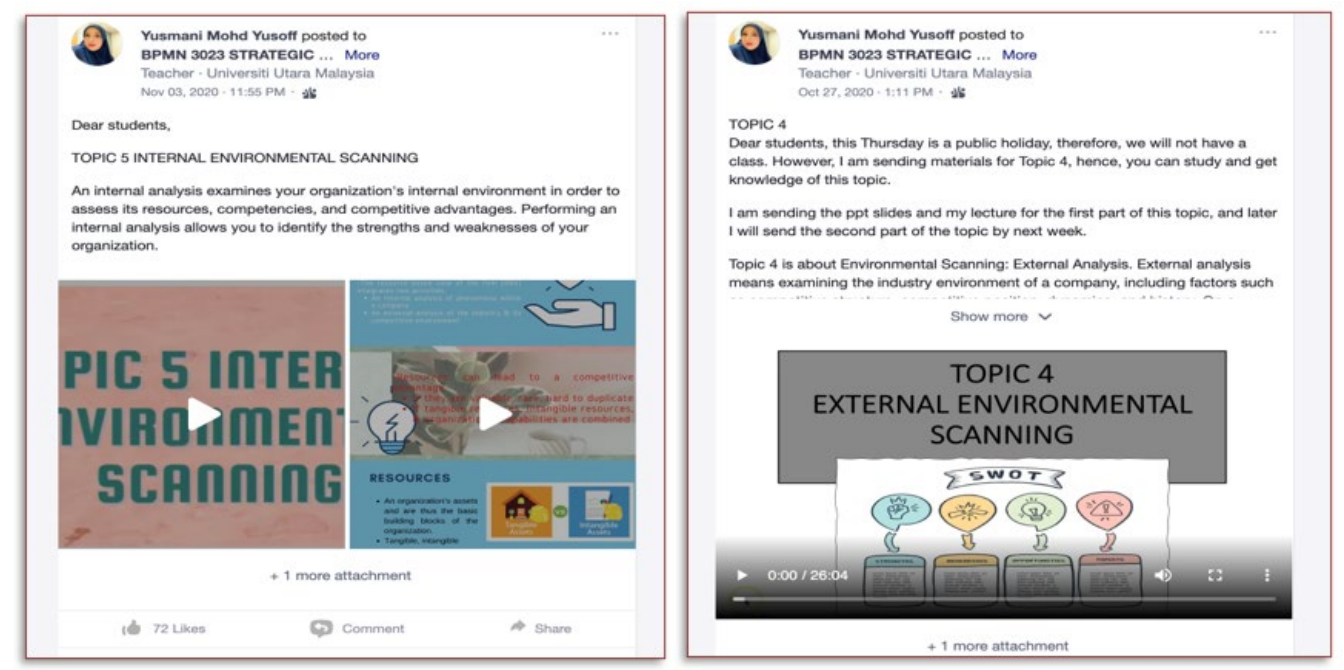

Figure 3 Example of the videos for the flipped classroom Strategic Management

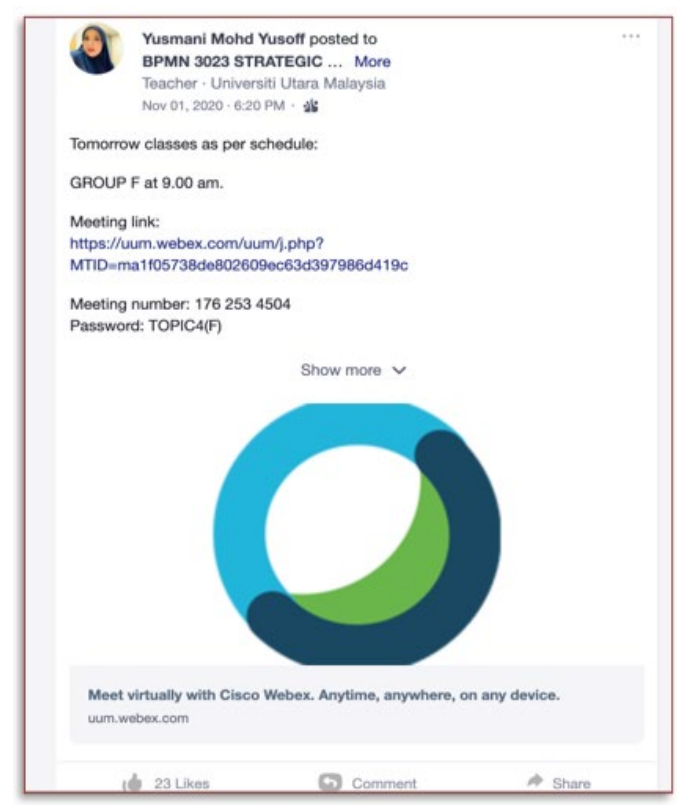

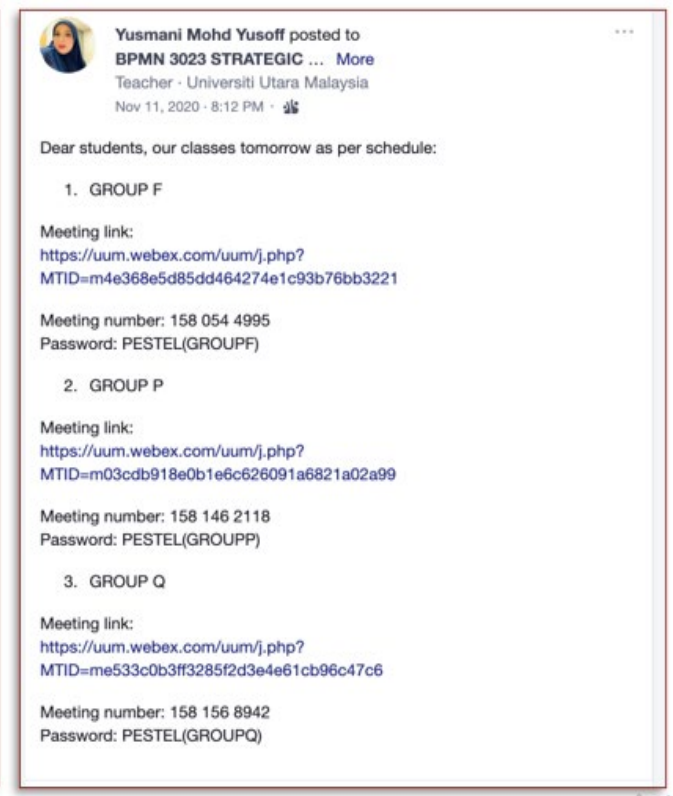

Figure 4 Schedule of online live streaming for Strategic Management

\section{METHODOLOGY}

The lecturer of the Strategic Management course intended to study the effectiveness of the combination between Edmodo and flipped classroom as an approach to enhance student engagement and online learning platform during COVIID-19 pandemic and blended learning method for the post-COVID-19 pandemic. The feedback was gathered from 230 students of the mentioned course in semester $12020 / 2021$ (Figure 5) based on ten open-ended questions posted in the Edmodo. The questions are as presented in Table 1. 


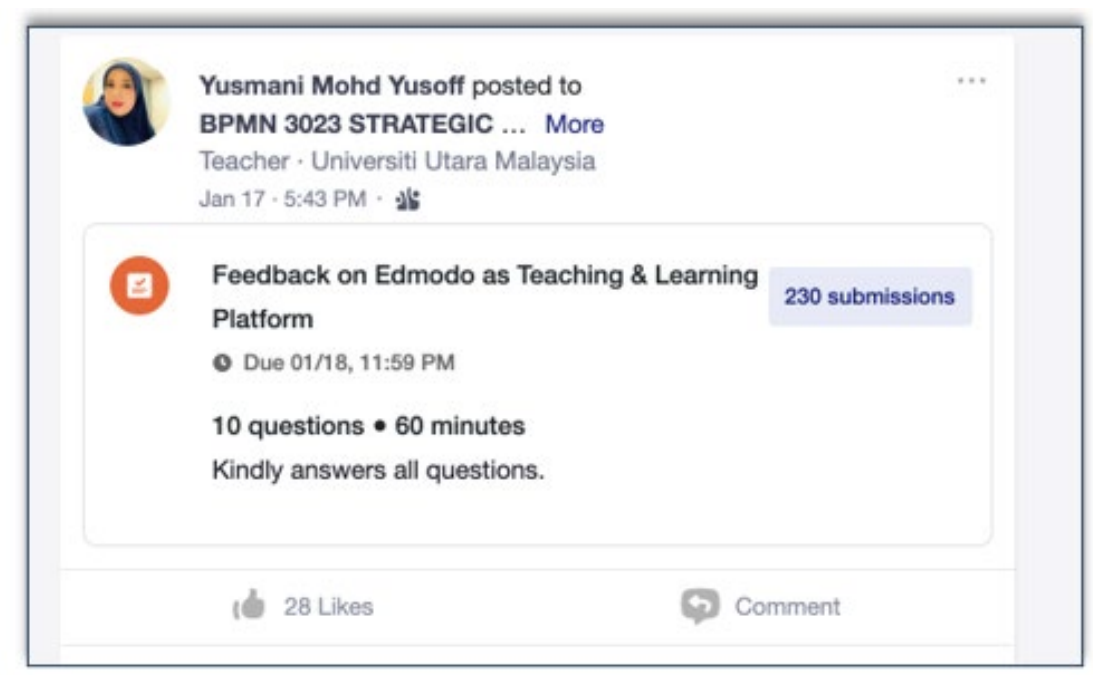

Figure 5 Feedback on the Model of Technology-Driven E-Flipped Classroom

Table 1 Open-ended Questions on the Feedback on Model of Technology-Driven E-Flipped Classroom

\begin{tabular}{cl} 
No. & \multicolumn{1}{c}{ Questions } \\
1 & I like to use Edmodo for online teaching and learning compared to UUM OL \\
2 & $\begin{array}{l}\text { I am confident when using Edmodo as a platform for online teaching and learning compared } \\
\text { to UUM OL }\end{array}$ \\
3 & I can get the resource easily from my lecturer using Edmodo \\
4 & Discussing online is fun especially through Edmodo \\
5 & I can reach my instructor easily in Edmodo \\
6 & $\begin{array}{l}\text { In your opinion, my recorded videos bring more understanding of the subject matters? and } \\
\text { making teaching with videos perfect for information retention? }\end{array}$ \\
7 & $\begin{array}{l}\text { In your opinion, videos are great for teaching concepts, practical, and which are best- } \\
\text { explained step-by-step? }\end{array}$ \\
8 & $\begin{array}{l}\text { The YouTube videos that I shared stimulate your cognitive processes of thinking, reasoning, } \\
\text { problem-solving, decision-making, and creativity? }\end{array}$ \\
9 & $\begin{array}{l}\text { The activities of teaching and learning using Edmodo (discussion, assignments, videos, } \\
\text { YouTube) during online sessions improved your understanding of the key concepts of the }\end{array}$ \\
& $\begin{array}{l}\text { Strategic Management subject? } \\
10\end{array}$ \\
\end{tabular}

Based on the feedback, the lecturer has analysed the result used the method of thematic analysis. According to Braun and Clarke (2012). the qualitative study uses thematic analysis "as a method a method for systematically identifying, organizing, and offering insight into patterns of meaning (themes) across a data set". Therefore, all students' reflections were put under specific themes to obtain the intended objective of this study.

\section{FINDINGS}

\section{Using Edmodo as Implementation Platform Software}

Edmodo can be a significant platform for online learning and online learning as it can be engaged in the flipped classroom in the event of a crisis such as COVID-19, 
where face-to-face interaction is not allowed. Furthermore, this new method (Edmodo \& flipping the class classroom) can be used to support flexible blended learning after the COVID-19 pandemic in increasing student engagement in the subject of Strategic Management. It can be sseen from the results of the study that 97 per cent of 230 students claimed that they like to use Edmodo compared to the university's online learning portal. Students stated that:

"Yes. I like to use Edmodo for online teaching and learning compare to UUM OL because it's more convenient and also easy for students to communicate with lecturer since Edmodo have comment section. Also, I like to use Edmodo because UUM OL always breakdown and I can't open it sometimes and make me frustrated".

"I think It one of good platform for teaching \& learning as student will receive new notification via email. By doing that student will alert with new topic or assessment on that day".

"Yes, because Edmodo like Facebook can comment and share and relatively smooth compare to UUM OL".

Furthermore, 98 per cent of the students are confident when using Edmodo as a platform for online teaching and learning compared to the university's online learning portal. Students claimed that:

"Yes, I am confident when using Edmodo as a platform for online teaching and learning compared to UUM OL. Even I never use Edmodo before, it's easier and more effective for me because when lecturer post something, it will be in top of Edmodo compared to UUM OL".

"I love using Edmodo because I can easily and quickly access to all the learning materials. All the students also can directly comment, ask a question and have a conversation with lecturer in this Edmodo platform. This platform does not easily lag, and hang compared to when I use UUM OL".

In terms of a resource accessibility, 98 percent of the students agreed that they can get the resources (video lectures, teaching materials, case studies, etc.) easily using Edmodo as an online learning platform. The students mentioned

"Definitely yes. Because it will notify me when lecturer post it at Edmodo. I can just scroll it and watch the video through phone at any time".

"Of course. I can directly open and download all the file upload by Dr. I also get a notification through my Gmail account every time Dr upload or post anything in Edmodo. This is very helpful for me".

"Yes. It easier to download the notes, easy to submit work and easy to watch the video that sent by lecturer".

"Yes, meaning that I no need to find one by one like OL. For example, like, every posting is attractive like social media, Facebook, so that we will read the post anywhere and anytime and download the notes and video on the spot or without download, we can just read it at the platform". 


\section{Offline Content Creation (flipped classroom -video)}

All of these 230 students agreed that the lecturer's recorded videos bring more understanding of the subject matters. According to the students, the lecturers' recorded video enabled them understanding the teaching content better as they can always refer back to the recorded videos during their revision. Undoubtedly, and this method is a helpful way during online learning as some of the students have limited access due to poor internet connection during a live online class. Furthermore, students also mentioned that using recorded video before living online class is very helpful as during the live class with our Webex, they need to focus during the learning session because if they miss any info, they are not able to re-watch the session unless the lecturer gives the recorded lecture, or they personally record the lecture. They stated that:

"Yes. I love when madam recorded video for our topic because your explanation brings more understanding as well when you do online class. And we can re-watch the video".

"Yes, because I can always refer back to the video when I am doing the revision, and this will help me to better understand the chapter".

"Yes, the recorded lectures are more understandable and informative. This is because I can watch and re-watch it anytime. Usually when we meet in WebEx, we need to really focus during the learning session because if we miss any info, we cannot re-watch the session unless if we personally record it by ourselves. The recorded video is very helpful because I can play and pause it every time that I want. Thank you so much Dr.".

"The recorded videos are very helpful especially during this pandemic where most of the students have limited access to the internet and easily get interrupted during online class. Recorded video also gives a chance to the students to rewind again and again if cannot catch up with the lecturer's explanation".

Moreover, 100 percent of the students agreed that the videos are great for teaching concepts that are practical, and for subjects which are best-explained stepby-step, especially when they have to fully under online class during this COVID-19 pandemic. They claimed that:

"In my opinion, videos are great and much better for teaching concepts that are practical and the best-explained step-by-step. As I mentioned before, we can get more information that we may missed before, and we also can watch it many times for better understanding".

"Yes, make me more attractive to join the class. I like a colorful notes and animation video. I really appreciate how Dr. present every topic to us like provide us with video to avoid boring".

"Yes, it would be boring sitting in front of laptop after attending direct online classes instead this method enables me to watch the videos during free time and interesting as well. Through the videos, lecturer also explained everything clearly, that's the best part of this class. Thank you, madam,". 
"From my point of view, video is great for teaching concepts because sometimes we can't get properly or understand what lecturer trying to say. So, by having this recorded video we as a student can refer back whenever we don't understand about that particular topic".

"Yes, from the video lecturer will explain it one by one and while doing assignment lecturer explain about the task with detail and that I and my group understand it and can do our assignment".

"Yes, I think video is the great for teaching concepts that are practical. This because through one session only we cannot digest all information in short time. Therefore, with video we can refer it back when we do not understand the topic".

"In my opinion, videos are great for teaching concepts that are practical because videos increase student engagement, which in turn helps boost achievement and they offer the flexibility to pause, rewind, or skip throughout the video to have class discussions or review particular areas. besides, they enable teachers to create a flipped classroom or "blended" learning environment".

However, only 90 per cent of 230 students agreed the YouTube videos that have been using by the lecturer stimulate their cognitive processes of thinking, reasoning, problem-solving, and decision-making. They stated that:

"Yes. We can get more extra information from the link that Dr. shared to us. From the video, I can think more and related to the theory that I had learnt".

"Indeed. The Youtube videos that Dr. shared stimulate my cognitive processes of thinking, reasoning, problem-solving, decision-making and creating because these videos had a detail explanation and also was explain in a simple way and make us more understand".

"Obviously yes. I gained a lot of knowledge especially on corporate level strategy $n$ business strategy".

\section{Students Engagement using Edmodo and Flipped Classroom}

96 per cent of the respondents agreed that the discussion during online learning, especially through Edmodo is interesting as Edmodo has a comment section just like Facebook where they can communicate with the lecturer, among their classmates, and see the comments between lecturer and other classmates as well. They mentioned that

"Yes. I can see the communication between Dr. and students through the comments".

"Indeed. For me, discussing through online is fun when using Edmodo because Edmodo have comment section just like Facebook. So, it's more fun to discuss with classmate".

"Yes, because we can directly comment on all the post that Dr posted in the Edmodo. We can like the post too. It feels like we are directly communicating with you just like when we use Instagram, Twitter and Facebook hehehehe". 
In terms of accessibility towards the lecturer, 98 per cent of the students agreed they can reach their lecturer easily via Edmodo as when any of the classmates or lecturer post/comment in the Edmodo, the students will get a notification through email. Therefore, they can comment back to the posts, and this justifies the effectiveness of Edmodo as a three-way communication channel, students and lecturer, lecturer and students, and students and students. Students claimed that:

"Yes. There is always got a reply of answer whenever there is a question".

"Yes. I can reach my instructor easily in Edmodo because when someone post something in Edmodo, we will get notification through email. So, we can comment on that post or just sent message through Edmodo".

"I think so. Because Dr can directly read our comment below the post and directly reply to our comment. If in UUM OL we can only comment through chat that lecturer provided, and the lecturer usually does not comment back. The student might not notice if the lecturer replies back because we do not receive any notification".

In terms of the effectiveness of online learning platform, 98 per cent of the students agreed that the teaching and learning activities using Edmodo such as discussion, assignments, videos, YouTube videos, improved their understanding of the key concepts of the subject matters. The students mentioned that:

"Sure. I had gotten many information and key concepts of the strategic management when I am doing all of the discussion, assignments as well as watching the recorded video and YouTube link. I know the process of strategic management including internal and external analysis, formulation, implementation as well as evaluation and control".

"The activities of teaching and learning using Edmodo during online sessions had improved my understanding of the key concepts of the Strategic Management subject".

"Yes. In my opinion, I think the assignment (mainly on Audit Strategic Report) had improved my understanding of the key concepts as we need to do it "practically"."

"Yes, compared to virtual class, activities of teaching and learning using Edmodo is much better. This is because Strategic Management is full of theories so that different teaching platform will always make us more interest".

"Honestly, Strategic Management is the best subject I've taken this semester because of the new teaching and learning approach which always remind me every time via email when Dr put something in Edmodo compared to UUM OL. So, I will access the content and it really help me in enhance understanding of the key concepts".

Hence, this study found that 90 of the students agreed that the usage of Edmodo as a teaching and learning platform due to the convenience of the accessibility as compared to the other platforms. 70 per cent of them agreed this platform is more engaging and interesting as they will receive a notification whenever any of the class members (lecturer or classmates) sent any information or shared any materials and contents. The students stated that: 
"Yes. I think Edmodo will be able to make those students that are shy or not willing to "speak" during the class, then this platform could try to make those students be more interactive with lecturers and other students".

"I have never use Edmodo before so this still new to me. But it is very easy to understand how Edmodo works very effectively used as a teaching and learning platform. Next, I think Edmodo is more interesting since everybody give a chance to comment and communicate with the lecturer. Sometime, in traditional class students feel shy to ask question or give comment".

Furthermore, this platform is more effective because each member can access any information, videos, slides, and other assignments at any time. Students mentioned that:

"Yes, Edmodo was more engaging and interesting in comparison to a traditional class".

"I think this platform is more interesting compared to traditional class. This because students can access this platform anytime, they want, and all information are in the platform. If traditional class, students can get the information during class only".

"Overall using Edmodo is a new experience and easy to access, this method is more engaging compared to the traditional class as we able to comment and upload the assignment and material at the same time".

"I agree that using Edmodo platform as a teaching and learning material is very effective and more engaging. I believe that all students will love this platform more than UUM OL. I really hope that Dr can continue use this platform for your next semester students if we need to proceed with the online learning again next semester. Thank you so much Dr".

However, 40 per cent of them still believe that the traditional classroom is more efficient compared to the online classroom as they claimed this online learning is less engaging and interesting as one of them claimed that:

"This method was less engaging and interesting in comparison to a traditional class".

"In my opinion, Edmodo is a brand-new learning platform for me as I never used it, but it is friendly and functionable platform. However, I prefer traditional class because the feeling is difference when study together in a classroom compared to online class".

"Traditional class is more conducive because it allows us to interact face to face and knowing each other. However, if for online, I really like this platform rather than others because of interesting to engage and gain knowledge".

\section{DISCUSSIONS}

During COVID 19 crisis, Edmodo is a significant platform for online learning since face-to-face learning is not permitted. This new method can be used to support existing flexible blended learning for the Strategic Management subject. The finding 
shows that students like and confident of using Edmodo compared to the university's online learning portal. Furthermore, they can easily obtain the resources such video lectures, teaching materials, case studies, etc by using Edmodo. Thus, from the students' feedback, we can conclude that the Edmodo can be incorporated into Strategic Management classrooms as an online learning platform especially during the COVID-19 pandemic and for a variety of uses. Lecturers can utilise the usage of Edmodo to facilitate class materials and become a useful platform for the flipped classroom platform.

According to Sohrabi and Iraj (2016). the flipped classroom is a new instructional model when the lecturer informs and provides in advance the activity that will be carried out during their teaching. This has allowed students to prepare and learn the specific contents/subjects at home, and when they come to class, they can engage more effectively. The finding of this study also indicate that all students agreed that the lecturer's recorded videos bring more understanding of the subject matters. Video recording is a helpful tool for some of the students who have limited internet data or experienced poor internet connection during an online class. Students can easily re-watch the video recordings during their revision. Hence, majority of the students agreed that video recordings are great for teaching concepts that are practical, and which are best-explained step-by-step, especially when students have to undergo online class fully during this COVID-19 pandemic. Furthermore, learning through video is more effective and it will definitely increase student engagement.

Majority of students agreed that the discussion during online learning especially through Edmodo is interesting. The design and functionality of Edmodo is similar to the Facebook as the homepage features a customizable news feed and a drop-down list of activity notifications where students can easily communicate with the lecturer and classmates. In terms of the effectiveness of Edmodo as an online learning platform, majority of respondents agreed that the activities of teaching and learning using Edmodo such as discussion, assignments, videos, YouTube videos, improved their understanding of the key concepts of the subject matters.

The most interesting findings revealed from this study is the students feel comfortable to participate in discussion using this platform as nobody can see their face compared to traditional face-to-face class. In addition, this platform is more effective because every student can obtain any information, videos, slides and other assignments at their own convenience. However, based on findings, 40 percent of respondents prefer the traditional classroom compared to online platform. They believe that face-to-face class is more efficient as they claimed this online learning is less engaging and has a human touch.

Based on the overall students' feedback, it shows that the combination of Edmodo as an online learning platform and flipped classroom approach enhances students' engagement in the Strategic Management subject through online activities carried out on their self-paced learning styles. Students are more engaging in the online streaming class, as they have been exposed to the content before the live online class. The students have the opportunity to spend a longer period of understanding, problem-solving, time practicing, and discussing their learning in online streaming class, especially in our standard online streaming class lesson where the time is limited; 1 hour and 30 minutes to teach the lesson and to discuss. 


\section{CONCLUSION}

The study shows that the combination of Edmodo and flipped classroom can be a valuable strategy to be considered for actively and deeply engaging students in the Strategic Management subject. Besides, the findings suggested that it can be adapted as an online learning model across all levels in higher education during and after the COVID-19 pandemic. The combination of these two approaches can be tailored and fully adapted to a variety of teaching and learning programmes and a range of subject contexts by practitioners and the combination works appropriately in online learning (during COVID-19) and blended learning (post COVID-19 pandemic). Furthermore, the combination of Edmodo and flipped classroom can engage various students in broad ways, and help students establish active learning habits with the support of ample resources (videos/materials) before class and enable deeper engagement in online learning. For the Strategic Management subject, this new model of the technology-driven e-flipped classroom has proven to stimulate active engagement among the students and should be considered as a new format for online teaching and learning and blended learning. Overall, the model has helped the students to demonstrate a remarkable commitment; signifying student engagement as intended. It is delightfully to report that the students are comfortable in communicating to their peers and lecturer virtually, in contrast to the face-to-face approach.

\section{REFERENCES}

Braun, V., \& Clarke, V. (2012). Thematic analysis. Retrieved from https://doi.org/10.1037/13620-004

Bulger, M. E., Mayer, R. E., Almeroth, K. C., \& Blau, S. D. (2008). Measuring learner engagement in computer-equipped college classrooms. Journal of Educational Multimedia and Hypermedia, 17(2), 129-143. Retrieved from https://www.learntechlib.org/p/23524/

Chen, F., Lui, A. M., \& Martinelli, S. M. (2017). A systematic review of the effectiveness of flipped classrooms in medical education. Medical education, 51(6), 585597. Retrieved from https://doi.org/10.1111/medu.13272

Martin, F., \& Bolliger, D. U. (2018). Engagement matters: Student perceptions on the importance of engagement strategies in the online learning environment. Online Learning, 22(1), 205-222. Retrieved from https://doi.org/10.24059/olj.v22i1.1092

Murillo-Zamorano, L. R., Sánchez, J. Á. L., \& Godoy-Caballero, A. L. (2019). How the flipped classroom affects knowledge, skills, and engagement in higher education: Effects on students' satisfaction. Computers \& Education, 141, 103608 Retrieved from https://doi.org/10.1016/j.compedu.2019.103608

Parusheva, S., Aleksandrova, Y., \& Hadzhikolev, A. (2018). Use of Social Media in Higher Education Institutions-an Empirical Study Based on Bulgarian Learning Experience. Tem Journal, 7(1), 171. Retrieved from https://www.ceeol.com/search/article-detail?id=616234

Rajaendram, Rebecca Grace. (2020) "Learning Mustn't Stop with Covid-19." The Star Online, 29 Mar., $\quad$ Retrieved www.thestar.com.my/news/education/2020/03/29/learning-mustntstop-with-covid-19 
Sohrabi, B., \& Iraj, H. (2016). Implementing flipped classroom using digital media : A comparison of two demographically different groups perceptions. Computers in Human Behavior, 60, 514-524. Retrieved from https://doi.org/10.1016/j.chb.2016.02.056

UNESCO. (2020). Education emergencies. Retrieved March 28, 2020 from Retrieved from https://en.unesco.org/themes/education-emergencies/coronavirusschool-closures 